\title{
An Investigation of Creativity Among Children in Kindergartens, Primary, Middle and High Schools
}

\author{
Aysel KÖKSAL AKYOL * Güneş SALI ${ }^{* *}$
}

Received: 15 January 2015

Accepted: 05 November 2015

\begin{abstract}
This study, which has a correlational survey design, aims to investigate creativity among children in kindergartens, primary, middle and high schools. The population of this study is comprised of all children attending kindergartens, primary, middle and high schools in the 2011-2012 academic years. The sample of the study consisted of a total of 1200 students, 100 of whom were randomly selected from each level of education. For some reasons, some cases were omitted, and analyses were done using the data of 1085 students. As a result of the study, it was observed that gender caused major differences regarding fluency in children attending kindergartens, elaboration and resistance to premature closure in children middle schools, and regarding originality, abstractness of titles, and elaboration and total creativity in children attending to high schools. It was found out that the average creativity score of girls were higher than those of boys $(p<0.05)$. Besides, the scores for fluency, elaboration, and resistance to premature closure and total creativity differed on the level of education $(p<0.05)$.
\end{abstract}

Keywords: Kindergarten, primary school, middle school, high school, creativity, gender, class level.

\section{Extended Abstract}

Purpose and Significance: It is observed that there are some surveys in our country regarding creativity, which are conducted with different age groups. However, there is no single research, which investigates creativity of children at different levels of education. Taking this as a point of departure, it is aimed to investigate creativity of children in kindergartens, primary, middle and high schools.

Methods: This study has a correlational survey design. The population of the current study is comprised of all children attending kindergartens, primary, middle and high schools in the 2011-2012 academic years. The sample of this study consisted of 1200 students, 100 of whom were randomly selected from each level of education. The majority of children attending the $12^{\text {th }}$ grade did not want to participate in the study due to the fact that they were preparing for the university entrance exam. Therefore, $12^{\text {th }}$ graders were excluded from the research. For some reasons, some cases were omitted, and the analyses were done using the data of 1085 students. General Information Form and Torrance Creative Thinking Test A Form were used as the data collection tools in the survey. As analyses of the study, Kolmogorov Smirnov (K-S) and Levene F tests

\footnotetext{
* Corresponding Author: Prof. Dr., Ankara University, Ankara, Turkey, koksalaysel@gmail.com

** Assist. Prof. Dr., Bozok University, Yozgat, Turkey, gunes.sali@bozok.edu.tr
}

\section{Citation Information}

Köksal-Akyol, A. \& Güneş, S. (2016). Anasınıfına, ilköğretime ve liseye devam eden çocukların yaratıcılıklarının incelenmesi. Kuramsal Eğitimbilim Dergisi [Journal of Theoretical Educational Science], 9(3), 379-399. 
were used in addition to the $t$-Tests, one-way analysis of variance (ANOVA) and Scheffe test.

Results: As a result of the current study, it was observed that gender caused major differences regarding fluency in children attending kindergartens, elaboration and resistance to premature closure in children middle schools, and regarding originality, abstractness of titles, and elaboration and total creativity in children attending to high schools. It was found out that the average creativity score of girls were higher than those of boys $(p<0.05)$. Besides, the scores for fluency, elaboration, and resistance to premature closure and total creativity differed on the level of education $(p<0.05)$.

Discussion and Conclusions: The results of the present study aimed to investigate creativity of children in kindergartens, primary, middle and high schools and suggested that the average scores of children attending to kindergartens $\left[\left(\bar{x}_{A}=24.68\right)\left(\bar{x}_{O}=20.13\right)\right.$ $\left.\left(\bar{x}_{B S}=1.14\right)\left(\bar{x}_{Z}=7.24\right)\left(\bar{x}_{\text {EKD }}=10.39\right)\left(\bar{x}_{T O P}=20.50\right)\right]$ were higher than those of children attending the first grade $\left[\left(\bar{x}_{A}=21.92\right)\left(\bar{x}_{O}=15.29\right)\left(\bar{x}_{B S}=.84\right)\left(\bar{x}_{Z}=6.99\right)\left(\bar{x}_{E K D}=8.71\right)\right.$ $\left.\left(\bar{x}_{\mathrm{TOP}}=16.21\right)\right]$ in all subscales of creativity and in total scores (Table 1). As consistent with findings of this study, a study conducted by Moran, Sawyers and Moore (1983) demonstrated that preschool children showed substantially more original reactions than did older children. These findings suggest that children spending time in formal school courses are affected by the restricted curricula, which do not allow original thinking. On the other hand, preschool children have not been introduced to the foregoing formal school courses, which are determined with strict rules (Isenberg \& Jalongo, 1973). Total creativity scores of all grades increase from the $3^{\text {rd }}$ to the $6^{\text {th }}$ grade $\left[\left(\bar{x}_{3 . S}=17.13\right)\right.$, $\left.\left(\bar{x}_{4 . S}=19.20\right), \quad\left(\bar{x}_{5 . S}=20.10\right), \quad\left(\bar{x}_{6 . S}=21.90\right)\right]$, decrease at the $7^{\text {th }}$ grade $\left(\bar{x}_{7 . S}=20.83\right)$, increase again in the $8^{\text {th }}$ grade $\left(\bar{x}_{8 . S}=21.85\right)$, reach to a peak in the $9^{\text {th }}$ grade $\left(\bar{x}_{9 . S}=24.10\right)$, and decrease in $10^{\text {th }}$ and $11^{\text {th }}$ grades $\left[\left(\bar{x}_{10 . S}=21.90\right)\left(\bar{x}_{11 . S}=20.20\right)\right]$. Many previous studies suggested that there was a general decrease in creativity skills between $6^{\text {th }}$ and $7^{\text {th }}$ grades (Torrance, 1962). Desire for acceptance by the opposite sex during the 13-15 age periods, i.e., the period of introduction to adolescence, may negatively affect creativity (Ataman, 1995). Despite all these negative results, creativity is still considered a significant educational output especially in the field of education (Aslan, 2007; Goree, 1996). All levels of education should cope with the problem of how to improve the learning process (Rowe, 2007). Today, educators have to think, conduct research, and arrange environments that would allow innovation, creativity, and democracy more than all the other periods of time (Sungur, 2001). For developing creativity, the significance of the qualities of teachers and the class atmosphere is an indisputable fact. Therefore, various recommendations with respect to organizing settings at schools that support and develop creativity of children were presented in line with the findings of this study. 


\title{
Anasınıfına, İlköğretime ve Liseye Devam Eden Çocukların Yaratıcılıklarının İncelenmesi
}

\author{
Aysel KÖKSAL AKYOL* \\ Güneş SALI ${ }^{* *}$
}

Makale Gönderme Tarihi: 15 Ocak 2015

Makale Kabul Tarihi: 5 Kasım 2015

\begin{abstract}
ÖZ: Anasınıfına, ilköğretime ve liseye devam eden çocukların yaratıcılıklarının incelenmesi amacıyla yapılan bu araştırmada betimsel yöntemlerden biri olan ilişkisel tarama modeli kullanılmıştır. Araştırmanın evrenini 2011-2012 eğitim-öğretim yılında anasınıflarına, ilköğretim 1. ve 2. kademeye ve liseye devam eden çocuklar oluşturmuştur. Araştırmanın örneklemini tesadüfi yöntemle belirlenen okullarda her sınıf düzeyinden tesadüfi yöntemle seçilen toplam 100'er çocuk olmak üzere toplam 1200 çocuk oluşturmuştur. Çeşitli nedenlerle bazı veri toplama araçları iptal edilmiş, analizler 1085 veri toplama aracı kullanılarak yapılmıştır. Araştırmada, t-Testi sonucuna göre, çocukların cinsiyetlerinin anasınıfına devam eden çocuklarda akıcılık; ilköğretim okulu ikinci kademeye devam eden çocuklarda zenginleştirme ve erken kapamaya direnç; liseye devam eden çocuklarda orijinallik, başlıkların soyutluğu, zenginleştirme alt boyutlarında ve toplam yaratıcılık puanında önemli bir farka neden olduğu gözlemlenmiştir. Kızların yaratıcılık puan ortalamalarının erkek çocuklarınkinden daha yüksek olduğu tespit edilmiştir $(p<0.05)$. Yapılan varyans analizi sonucunda da akıcılık, orijinallik, başlıkların soyutluğu, zenginleştirme, erken kapamaya direnç alt boyut puanlarının ve toplam yaratıcılık puanının çocukların devam ettikleri sınıf düzeylerine göre farklılaştığı belirlenmiştir ( $p<0.05)$.
\end{abstract}

Anahtar kelimeler: Anasınıfı, ilköğretim, lise, yaratıcılık, cinsiyet, sınıf düzeyi.

\section{Giriş}

İnsanın varoluşundan bu yana ona eşlik eden yaratıcılık, kolay tanımlanamayan, karmaşık bir süreçtir. Yaratıcılık başlangıçta benimsendiği gibi yalnız sanatsal süreçlerde ya da sanat eğitimi ve öğretimine ilişkin etkinliklerde rol oynayan bir yeti olmayıp (San, 1979), insan yaşamının ve insanlığın evriminin tüm yönlerinde yer alan temel bir yetenektir. İnsan tarafından tamamlanmış her işte yaratıcılık bir temel öge olarak bulunmaktadır. Yaratıcılık süreci, tüm duyuşsal ve düşünsel etkinliklerde, her türlü çalışma ve uğraşın içerisinde yer almaktadır (San, 1981, 1985). Torrance (1974 ) yaratıcılığı "sorunları, yetersizlikleri, bilgideki boşlukları, rahatsız edici ya da eksik öğeleri sezip, bunlar hakkında düşünceler geliştirmek, varsayımlar kurmak, bunları sınamak, sonuçları karşılaştırıp, değiştirmek ve yeniden sınamak" şeklinde tanımlarken (aktaran Davaslıgil, 1988, s.3), Bartlett (1958) "ana yoldan ayrılma, deneye açık olma, kalıplardan kurtulma" olarak nitelemiştir (aktaran San, 1985, s 9). Isbell ve Raines (2003), yaratıcılığ “önceki bilgi birikimi ve deneyimler ışığında yeni fikirler, çözümler ve/veya ürünler üretmek" olarak, Mayesky (2002) ise yaratıcılığ1 "bir düşünme, davranma şekli ya da birey için özgün olan ve diğerleri tarafından değerli kılınan bir şey yapma" şeklinde tanımlamıştır. Genel ve geniş bir tanımlama, "bilinen şeylerden yepyeni bir şeyler çıkarmak, yeni, özgün bir bireşime (sentez) varmak, birtakım sorunlara yeni çözüm yolları bulmak" şeklinde yapılabilir. Landau (1974) ise "yaratıcı yeti”yi, "daha önceden kurulmamış ilişkiler arasındaki ilişkileri kurabilme, böylece yeni bir düşünce şeması içinde, yeni yaşantılar, deneyimler, yeni düşünceler ve yeni ürünler ortaya koyabilme" olarak tanımlamıştır (aktaran San, 1985, s.10).

\footnotetext{
* Sorumlu Yazar: Prof. Dr., Ankara Üniversitesi, Ankara, Türkiye, koksalaysel@ gmail.com

*** Yrd. Doç. Dr., Bozok Üniversitesi, Ankara, Türkiye, gunes.sali@bozok.edu.tr
} 
Yaratıcı düşünme tek bir yetenek olmayıp, problemlere duyarlı olmayı, akıcılık, esneklik, özgünlük, zenginleştirme ve yeniden betimleme gibi çok sayıda yeteneği de içerir. Akıcılık bir problem için birçok alternatif geliştirebilme, çok sayıda fikir, düşünce ve çağrışım üretebilme, esneklik ise farklı kategorilere giren düşünce üretme yeteneği, aynı uyaranla ilgili değişik fikirler üretebilme veya problem çözümünde yaklaşımları değiştirme, birbirinden değişik yaklaşımlar kullanabilme anlamına gelmektedir. Özgünlük; eşsiz, rastlanmayan, akıllı düşünceler yaratma ya da yeni özel çözümler getirme, yeni, alışılmamış ve az rastlanan fikirler üretme olarak tanımlanırken, zenginleştirme verilen yalın bir uyaranı ayrıntılı ve özenli bir biçimde işleyip geliştirme, ayrıntılara girebilme, yanıtlar ekleme anlamında kullanılmaktadır. Yeniden betimleme ise alışılagelenden, kurulmuş olandan, istenilen yoldan farklı bir yol algılama veya betimleme olarak tanımlanmaktadır (Erlendsson, 1999; Öncü, 2003; Torrance \& Goff 1989). Söz konusu bu yetenekler sıklıkla yaratıcılığın alt boyutları olarak da ifade edilmektedir.

Yaratıcılığın yaşamın ilk yıllarından itibaren hızlı bir gelişim gösterdiği, çocukların çok erken yaşlardan itibaren bilgiyi yaratıcı bir şekilde organize etmeye başladığı, en iyi aşamasına çocukluğun ilk yıllarında ulaştığı, ancak sonraları yaratıcılığın gelişiminde düşme görüldüğü belirtilmektedir (Aral, 2004; Cho \& Kim, 1999; Kamaraj \& Aktan, 1988). Çocuklar iki yaşında nesneleri tanıyıp kullanmaya ve çevresini keşfetmeye başlamaktadır. İki-dört yaşlar arasında, denetimsiz hareketlerden dengeli fiziksel güce ve imgeleme gücüne dayanan etkinliğe geçiş olmaktadır. Dört-altı yaşları arasında çocuk, planlama yapma becerisini öğrenmeye başlar. Önceden bildiği oyunları planlamaktan çok hoşlanır. Merakı sayesinde doğruyu ve yanlışı öğrenir, hayali oyunlarında birçok rolü dener (Argun, 2004; Ömeroğlu \& Turla, 2001). Alt1-sekiz yaşlar arasındaki çocuklar oyunlarında bile gerçeği arama çabası içine girmişlerdir. Torrance (1962)'ın gözlemlerine göre; pek çok çocuk birinci ve ikinci sınıflarda tüm fantezilerini bir tarafa atmakta ve çocuğun hayal güçlerinde düşüşler görülmektedir. Yetişkinler tarafından kısıtlanmadığ 1 takdirde merak, gelişmeye devam etmektedir (Çakmak, 2005; San, 1979; Torrance, 1962). Sekiz-on yaşları arasında çeşitli yaratıcı becerilerin kullanımı artmakta ve çocuk kendi yeteneklerini yaratıcı olarak kullanma yollarını keşfedebilmekte, güçlükleri yenen kahramanlarla özdeşleşmekten hoşlanmaktadır. Bu dönemde, ilgi ve çaba gerektiren projeleri üstlenebilmektedirler. On-on iki yaşlarında çocuklar keşiflerden hoşlanmaktadırlar. Bu yaşlarda çocuklar, artık daha uzun sürelerle okuyabilir ya da düşünebilirler. Bu dönemde müzik yeteneği ve diğer sanatsal yetenekler hızla gelişir. Zihinsel olgunlaşmayla birlikte çocuğun çözümsel davranışları da artmaktadır (Çağatay-Aral, 1990; Çakmak, 2005; Öncü, 1989; Torrance, 1962). En yoğun yaratıcı becerilerin sergilendiği dönemin ise on üç-on dört yaşları olduğu belirtilmektedir. Bu dönemden sonra yaratıcılık, ya belli bir düzeyde devam etmekte ya da düşüş gösterebilmektedir. Tepe noktaya ulaşma konusunda bireysel farklılıklar söz konusu olmaktadır (Güleryüz, 2001). Ergenliğe giriş dönemi olan on üç-on beş yaş döneminde karşı cins tarafından benimsenme arzusu yaratıcılığ 1 olumsuz yönde etkileyebilmektedir. On yedi-on dokuz yaş döneminde ise meslek seçimi, üniversiteye giriş dönemi yaratıcılığ gerileten bir başka nedendir (Ataman, 
1995). Görüldüğü gibi yaş ilerledikçe çocuğun yaratıcılığında bir gerileme söz konusu olabilmektedir. Moran, Sawyers ve Moore (1988) yaptıkları bir araştırmada okul öncesi çocuklarının daha büyük yaştaki çocuklara göre daha geniş oranda orijinal tepki gösterdiklerini bulmuşlardır. Bu bulgular formal okul dersleriyle çok zaman harcayan okul çocuklarının sınırlandırılmış ve orijinal düşünmeye izin vermeyen eğitim programlarından etkilendiğini göstermektedir. Oysa okul öncesi yaş dönemindeki çocuklar bu katı kurallarla belirlenmiş formal okul dersleriyle henüz karşılaşmamışlardır (Isenberg \& Jalongo, 1973). Genel olarak okul öncesi dönem çocuğunun yaratıcılığa yaklaşımı çok daha özgür ve yalındır. Bu dönemde çocuklar, öz bilinçleri tam gelişmemiş olduğundan, yaratıcı etkinliklerde kendilerini ifade etme yolları konusunda çok yaratıcı ve güvenlidirler. İlkokul döneminde ise çocuk artık bazı şeyler hakkında bilgi sahibi olmuştur. Her sorunun kesin bir çözümü olmadığını da öğrenmiştir. Özbilinçlerinin gelişmişliğine egemen olmalarına karşın, yaratıcı etkinliklerinde amaçlarına ulaşabileceklerinden kuşkuludurlar (San, 1979). Çevre, çocukların yaratıcılıklarını geliştirebileceği gibi bu ortamlardaki olumsuz koşullar ise yaratıcılığı kısıtlayabilmektedir (Cho \& Kim, 1999). Yapılan bazı araştırmalar da sınıf düzeyi yükseldikçe özellikle de altı ve yedinci sınıflarda yaratıcı yeteneklerde genel bir azalmanın olduğu ortaya koymuşlardır. Bazı araştırmalarda bu azalmanın sekizinci sınıflarda da (14 yaş) olduğunu görülmüştür (aktaran Torrance, 1962).

Eğitim sistemlerinin olumsuz etkilerine rağmen yine de yaratıcılık kavramı, özellikle de eğitim alanında, önemli bir eğitim çıktısı olarak kabul edilir (Aslan, 2007; Goree, 1996). Eğitim kurumları yaratıcı düşünen bireyler yetiştirme, bireylerin var olan potansiyellerini koruma ve geliştirme işlevini gerçekleştirme sorumluluğunu üstlenir (Aslan, 2007; Black, 2003; Yıldız, Özkal \& Çetingöz, 2003). Yaratıcılık ancak bilişsel, duyuşsal ve devinsel bir kültürel etkinlik sonucu ortaya çıkar. $\mathrm{Bu}$ da sadece yaratıcı eğitim ile mümkün olabilir. $\mathrm{Bu}$ nedenle eğitim ortamı, öğrencilerin problemi fark etmelerine, tanılayıp gerekli denenceleri geliştirmelerine ve ortak çalışmalara firsat verecek yapıda olmalıdır (Sönmez, 1993). Okul öncesinden başlayarak, zengin olumlu ve yapıcı deneyimler sunarak, sürekli destekleyip cesaretlendirerek çocukları yaşama hazırlamalıdır (Aral ve diğerleri, 2007; Aslan, 2007; Berratta \& Privette, 1990; Mangır \& Aral, 1992; Yıldız ve diğerleri, 2003)

Literatür incelendiğinde dokuz ve on dört yaşlarındaki çocukların yaratıcılıkları ile sosyo-ekonomik düzey ve cinsiyetleri arasındaki ilişkinin (Aral, 1992, 1996), anaokuluna devam eden çocukların anne-baba tutumları ile yaratıcı düşünmeleri arasındaki ilişkinin (Dinçer, 1993), yedi-on bir yaş çocuklarının yaratıcılığ 1 ve kişilik yapılarının (Öncü, 1989) incelendiği görülmektedir. Bunun yanı sıra on iki-on dört yaşları arasındaki çocukların yaratıcılık düzeylerinin yaş ve cinsiyete göre karşılaştırılması (Öncü, 2003), yaratıcılık programının dört-beş yaş çocuklarının sosyal ve bilişsel gelişimlerine etkileri (Yıldız, 2000), ilköğretim altıncı sınıf öğrencilerinin yaratıcı düşünme düzeyleri (Ersoy \& Başer, 2009), beş-altı yaş çocuklarının yaratıcılık ve ögrenime hazır oluş düzeylerine okulöncesi eğitimin etkisi (Akçum, 2005), okul öncesi eğitime devam eden beş-altı yaş çocuklarının bilişsel tempoya göre yaratıcılık 
düzeyleri (Ceylan, 2008), okul öncesi eğitim kurumlarına devam eden beş yaş çocuklarının yaratıcıılıları (Atay, 2009), köyde ve kentte yaşayan altı yaş çocuklarının yaratıcılıklarının karşılaştırılması (Çakmak \& Baran, 2006), sınıf düzeyi ve yaratıcılık (Alacapınar, 2013) gibi konuların incelendiği araştırmalara da rastlanmaktadır. Ülkemizde yaratıcıllğa ilişkin değişik yaş gruplarına yönelik araştırmaların olduğu görülmekte ancak okul öncesi, ilköğretim ve lise kademelerine devam etmekte olan geniş bir yaş aralığındaki çocukların yaratıcılıklarının incelendiği bir çalışma bulunmamaktadır. Bu noktadan hareketle bu araştırmada anasınıfına, ilköğretime ve liseye devam eden çocukların yaratııılıklarının incelenmesi amaçlanmıştır.

\section{Yöntem}

\section{Araştırmanın Modeli}

Anasınıfına, ilköğretime ve liseye devam eden çocukların yaratıcılıklarının incelenmesi amacıyla yapılan bu araştırmada betimsel yöntemlerden biri olan ilişkisel tarama modeli kullanılmıştır. Tarama modeli, geçmişte ya da şu anda var olan bir durumu var olduğu biçimiyle anlatmayı amaçlayan bir araştırma biçimidir. Tarama modelinde araştırmaya konu olan birey ya da nesne, kendi koşulları içinde var olduğu gibi tanımlanmaya çalışılır (Karasar, 1995).

\section{Evren ve Örneklem}

Araştırmanın evrenini 2011-2012 eğitim-öğretim yılında ana sınıflarına, ilköğretim 1. ve 2. kademeye ve liseye devam eden çocuklar oluşturmuştur. Araştırmanın örneklemini tesadüfi yöntemle belirlenen (bir genel lise, bir Anadolu lisesi, bünyesinde anasınıfi bulunan dört ilköğretim okulu) okullarda her sinıf düzeyinden tesadüfi yöntemle seçilen toplam 100 'er çocuk oluşturmuştur. 12. sinıf öğrencilerinin büyük bir çoğunluğu üniversiteye hazırlık döneminde olmaları nedeniyle araştırmaya katılmak istemediklerini bildirmişlerdir. Bu nedenle 12. sınıflar araştırmaya dahil edilmemiştir. Anasınıflarından, ilköğretim 1 ve 2. kademe sınıflarından ve 9, 10 ve 11. sinıflardan katılan toplam 1200 çocuk ile araştırma yürütülmüştür. Çeşitli nedenlerle bazı veri toplama araçları iptal edilmiş, analizler 1085 veri toplama aracı kullanılarak yapılmıştır. Örneklemin özellikleri Tablo 1' de verilmiştir. 
Tablo 1

Örneklemin Özellikleri

\begin{tabular}{lrrrrrr}
\hline & \multicolumn{2}{c}{ Kız } & \multicolumn{2}{c}{ Erkek } & \multicolumn{2}{c}{ Toplam } \\
\hline Anasınıfı & $\mathrm{n}$ & $\%$ & $\mathrm{n}$ & $\%$ & $\mathrm{n}$ & $\%$ \\
Birinci sınıf & 47 & 51.1 & 45 & 48.9 & 92 & 100 \\
İkinci sınıf & 43 & 47.3 & 48 & 52.7 & 91 & 100 \\
Üçüncü sınıf & 54 & 58.7 & 38 & 41.3 & 92 & 100 \\
Dördüncü sınıf & 45 & 50.0 & 45 & 50.0 & 90 & 100 \\
Beşinci sınıf & 51 & 55.4 & 41 & 44.6 & 92 & 100 \\
Altınci sınıf & 42 & 46.2 & 49 & 53.8 & 91 & 100 \\
Yedinci sınıf & 48 & 54.5 & 40 & 45.5 & 88 & 100 \\
Sekizinci sınıf & 40 & 46.6 & 51 & 53.4 & 91 & 100 \\
Dokuzuncu sinıf & 41 & 46.6 & 47 & 53.4 & 88 & 100 \\
Onuncu sınıf & 48 & 53.3 & 42 & 46.7 & 90 & 100 \\
Onbirinci sınıf & 44 & 48.9 & 46 & 51.1 & 90 & 100 \\
Toplam & 53 & 58.9 & 37 & 41.1 & 90 & 100 \\
\hline
\end{tabular}

\section{Veri Toplama Araçları}

Genel bilgi formu. Araştırmacılar tarafından geliştirilen form araştırmaya katılan çocuklara ilişkin demografik özelliklerin belirlenmesinde kullanılmıştır.

Torrance Yaratıcı Düşünce Ölçeği şekil form A. Torrance tarafından 1966 yılında geliştirilen test, sözel ve şekilsel kısımdan oluşmaktadır. Sözel ve şekilsel testlerin A ve B formları bulunmaktadır. Torrance Yaratıcı Düşünce sözel ve şekilsel testlerinde yer alan alt testler, sorun çözme için gerekli çok sayıda, olabildiğince farklı alanda ve oldukça az rastlanan ve yaratıcı güç gerektiren düşünceleri ortaya çıkarmayı amaçlamaktadır. Şekil testinde yaratıcılık; Akıcılık, Orijinallik, Başlıkların Soyutluğu, Zenginleştirme ve Erken Kapamaya Direnç alt boyutlarında değerlendirilmektedir. Bu çalışmada Şekil Form-A kullanılmıştır. Ölçeğin şekil formunda resim oluşturma, resim tamamlama ve paralel çizgiler olmak üzere üç alt test bulunmaktadır (Aslan, 2001).

Resim Oluşturma. Verilen geometrik şeklin tamamlanarak yeni bir şeklin oluşturulması ve bu yeni şekil ile ilgili bir hikâye oluşturulması ya da bir isim verilmesi istenmektedir.

Resim Tamamlama. On adet yarım bırakılmış çizginin çocuk tarafından yeni bir şekil hâline getirilmesi ve isimlendirilmesi istenmektedir. 
Paralel Çizgiler. Aynı tür uyarana verilebilecek farklı yanıtların test edilmesi amaçlanmaktadır. Verilen otuz adet paralel çizgi ile yeni şekiller oluşturulması ve isimlendirilmesi istenmektedir.

Testin değerlendirilmesinde norm dayanaklı ölçüler ve kriter dayanaklı ölçüler olmak üzere iki ölçü dikkate alınmaktadır. Norm dayanaklı ölçüler; Akıcılık, Orijinallik, Başlıkların Soyutluğu, Zenginleştirme ve Erken Kapamaya Direnç olmak üzere beş tanedir. Akıcılık puanı; resim tamamlama ve paralel çizgiler testinin, Orijinallik puanı; resim oluşturma, resim tamamlama ve paralel çizgiler testinin, Başlikların Soyutluğu puanı; resim oluşturma ve resim tamamlama testinin, Zenginleştirme puanı, resim oluşturma, resim tamamlama ve paralel çizgiler testinin, Erken Kapamaya Direnç puanı ise; resim tamamlama testinin değerlendirilmesi sonucu elde edilmektedir. Kriter dayanaklı ölçüler ise; 13 boyutta ele alınmaktadır. Her üç test için puanlar duygusal ifadeler, hikâye anlatma, hareket ya da faaliyet, başlıkların açıklayıcılığı, tamamlanmamış şekillerin birleştirilmesi, tamamlanmamış çizgilerin sentezi, alışılmadık görselleştirme, içsel görselleştirme, sınırları uzatma veya geçme, mizah, hayal gücü zenginliği, hayal gücü renkliliği ve fantezi boyutlarında değerlendirilmektedir (Aslan, 2001).

Torrance Yaratıcı Düşünce Ölçeği (Şekil Form-A)'nın değerlendirilmesi sonucunda; Akıcılık, Orijinallik, Başlıkların Soyutluğu, Zenginleştirme ve Erken Kapamaya Direnç boyutlarına ilişkin puanlar dışında, Yaratıcı Kuvvetler Listesi'ndeki kriterler dikkate alınarak Yaratıcı Kuvvetler Listesi'ne ait bir puan elde edilmektedir. Çocuğun beş boyuttan aldığı puanların ortalamasına Yaratıcı Kuvvetler Listesinde yer alan kriter dayanaklı ölçütlere ilişkin puanların toplamı ilave edilerek Toplam Yaratıcılık puanı hesaplanmaktadır (Aslan, 2001).

Torrance (1966) tarafından geliştirilen Torrance Yaratıcı Düşünce Ölçeği'nin sözel ve şekilsel kısımları Aslan (2001) tarafından Türkçeye uyarlanmış ve testin çevirisi, test maddelerinin Türkçeye adaptasyonu, Türkçeye çevirisinin geçerliği ve güvenirliği araştırılmıştır. İngilizce ve Türkçe test uygulamaları arasındaki korelasyon toplam şekilsel yaratıcılık için yüksek düzeyde anlamlı çıkmıştır $(\mathrm{r}=0.59)$. Elde edilen iç tutarlılık analizlerinde $\mathrm{r}=0.38$ ile $\mathrm{r}=0.89$ arasındadır. Okul öncesi grubunun en düşük Cronbach alfa değeri .50, en yüksek iç tutarlılık katsayısı .71 olarak belirlenmiştir. Geçerlik çalışmaları kapsamında ise iç geçerlik ve dış geçerlik çalışmaları yapıllmıştır. Kriter geçerliği başlığı altında sıfat listesi, Wechsler Yetişkinler Formu ve Wonderlic Personel Testi (Genel Yetenek Testi) kullanılmış ve yapılan analizler sonucunda, testin tüm yaş grupları ve puan türleri için güvenilir olduğu görülmüştür (Aslan, 2001).

\section{İşlem ve Uygulama}

Araştırma için gerekli izin Yozgat Valiliği İl Milli Eğitim Müdürlüğü’nden alınmıştır. Uygulama 2011-2012 eğitim-öğretim yılında ikinci dönem, Yozgat il merkezinde Milli Eğitim Müdürlüğü'ne bağlı iki lise ve dört ilköğretim okulunda gerçekleştirilmiştir. Araştırmada, uygulamaya başlamadan önce araştırmacılar tarafından okul yöneticileri ve öğretmenlerle bilgilendirme görüşmeleri yapılarak 
araştırmanın amacı genel olarak açıklanmış ve bilgi verilmiştir. Araştırmaya katılan anasınıfı ve birinci sınıf öğrencilerinin Genel Bilgi Formu araştırmacılar tarafından öğretmen desteği ile doldurulmuştur. Diğer sınıflarda ise öğrencilerin kendileri doldurmuşlardır. Torrance Yaratıcılık Ölçeği tüm sınıflarda küçük gruplar halinde ayrı ayrı olmak üzere, kendi okullarında sınıf ortamında uygulanmıştır. Uygulamaya başlamadan önce ölçekle ilgili gerekli açıklama yapılmıştır. Anasınıfı çocukları okuma yazma bilmediklerinden, yaptıkları çizimlerin ismini yazma konusunda, uygulayıcılar yardımcı olmuşlardır. Süreli bir test olması nedeniyle Torrance Yaratıcılık Ölçeği’nin uygulanması her oturumda 30 dakikada tamamlanmıştır. (Her üç etkinlik on dakika ile sınırlı olup, denekler etkinlikleri yaklaşık onar dakikalık süreler içinde tamamlamışlardır). Test süresince çocukların birbirlerinin çizimlerinden etkilenmemesi konusuna dikkat edilmiştir.

\section{Verilerin Analizi}

Araştırmada öğretmen adaylarının yapılandırmacı yaklaşımı uygulamaya yönelik öz yeterlik inançlarını belirlemek amacıyla betimsel istatistikler kullanılmıştır. Karşılaştırmalar için, öncelikle, öğretmen adaylarının ölçeğe verdikleri yanıtların her bir değişkene ilişkin ortalama ve standart sapmaları hesaplanmış, normallik ve varyansların homojenliği kontrol edilmiştir. Bu incelemelere göre; ikili karşılaştırmalarda t-testi, üçten daha fazla boyutu olan karşılaştırmada ise tek yönlü varyans analizi (ANOVA) kullanılmıştır. Anlamlı çıkan F değerleri için, farkın kaynağını belirlemek üzere, varyansların homojen olmasına bağlı olarak, çoklu karşılaştırma testlerinden Tukey testi kullanılmıştır.

\section{Bulgular}

Anasınıfına, ilköğretim birinci ve ikinci kademeye ve liseye devam eden çocukların yaratıcılıklarının incelenmesi amacıyla yapılan bu araştırmada elde edilen bulgular aşağıda sunulmuştur. 
Tablo 2

Anasınıfi, Illköğretim ve Liseye Devam Eden Çocukların Cinsiyetlerine Göre Yaratıcılıklarına Ait Ortalamalar, Standart Sapmalar ve t Testi Sonuçları

\begin{tabular}{|c|c|c|c|c|c|c|c|c|}
\hline KADEME & Yaratıcılık & Cinsiyet & $n$ & $\mathrm{X}$ & $S$ & $\mathrm{Sd}$ & $\mathrm{t}$ & $p$ \\
\hline \multirow{12}{*}{ 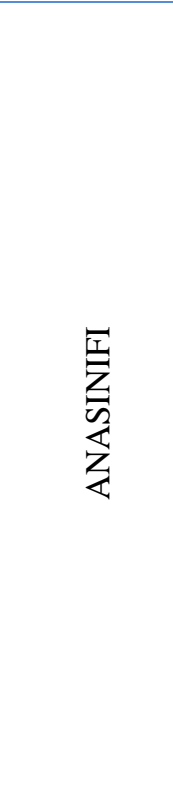 } & \multirow{3}{*}{ Akıcıllk } & $\mathrm{K} 1 \mathrm{z}$ & 47 & 26.70 & 8.51 & 90 & 2.258 & .026 \\
\hline & & Erkek & 45 & 22.58 & 9.01 & \multirow{3}{*}{90} & \multirow{3}{*}{-.793} & \multirow{3}{*}{.430} \\
\hline & & $\mathrm{K} 1 \mathrm{z}$ & 47 & 19.30 & 9.84 & & & \\
\hline & Orijinallik & Erkek & 45 & 21.00 & 10.75 & & & \\
\hline & Başlıkların & $\mathrm{K} ı \mathrm{z}$ & 47 & .81 & 1.64 & \multirow[b]{2}{*}{90} & \multirow{2}{*}{-1.785} & \multirow[b]{2}{*}{.078} \\
\hline & \multirow[t]{2}{*}{ Soyutluğu } & Erkek & 45 & 1.49 & 2.01 & & & \\
\hline & & $\mathrm{K} 1 \mathrm{z}$ & 47 & 7.17 & 2.70 & \multirow[t]{2}{*}{90} & \multirow[t]{2}{*}{-.186} & \multirow[t]{2}{*}{.853} \\
\hline & Zenginleştirme & Erkek & 45 & 7.31 & 4.39 & & & \\
\hline & Erken kapamaya & $\mathrm{K} 1 \mathrm{z}$ & 47 & 10.51 & 3.88 & \multirow[t]{2}{*}{90} & \multirow[t]{2}{*}{.287} & \multirow[t]{2}{*}{.774} \\
\hline & \multirow[t]{2}{*}{ Direnç } & Erkek & 45 & 10.27 & 4.26 & & & \\
\hline & & $\mathrm{K} 1 \mathrm{z}$ & 47 & 20.32 & 4.43 & \multirow{2}{*}{90} & \multirow{2}{*}{-.368} & \multirow{2}{*}{.714} \\
\hline & \multirow[t]{2}{*}{ Toplam yaratıcılık } & Erkek & 45 & 20.68 & 4.96 & & & \\
\hline \multirow{12}{*}{ 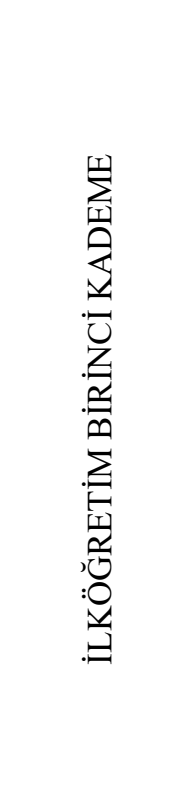 } & & $\mathrm{K} 1 \mathrm{z}$ & 235 & 23.22 & 8.09 & \multirow{2}{*}{454} & \multirow{2}{*}{.547} & \multirow{2}{*}{.585} \\
\hline & Akıcılık & Erkek & 221 & 22.82 & 7.60 & & & \\
\hline & \multirow[b]{2}{*}{ Orijinallik } & Kız & 235 & 17.31 & 7.05 & \multirow[b]{2}{*}{454} & & 710 \\
\hline & & Erkek & 221 & 17.08 & 6.56 & & .373 & .710 \\
\hline & Başlıkların & $\mathrm{K} 1 \mathrm{z}$ & 235 & 2.20 & 2.90 & & & \\
\hline & Soyutluğu & Erkek & 221 & 2.05 & 2.67 & 454 & .590 & .555 \\
\hline & & $\mathrm{K} 1 \mathrm{z}$ & 235 & 8.94 & 3.19 & 454 & 618 & 537 \\
\hline & Zenginleştirme & Erkek & 221 & 8.76 & 3.19 & 454 & & \\
\hline & Erken kapamaya & $\mathrm{K} 1 \mathrm{z}$ & 235 & 10.80 & 4.40 & 454 & 140 & 880 \\
\hline & direnç & Erkek & 221 & 10.74 & 4.48 & 434 & .140 & .007 \\
\hline & & $\mathrm{K} 1 \mathrm{z}$ & 235 & 18.44 & 5.54 & $1-1$ & & \\
\hline & Toplam yaratıcilık & Erkek & 221 & 18.27 & 5.45 & 434 & .322 & .141 \\
\hline$ت$ & & $\mathrm{~K} 1 \mathrm{z}$ & 129 & 24.52 & 7.39 & 265 & -921 & 358 \\
\hline$\underline{z}$ & Akıcıllk & Erkek & 138 & 25.36 & 7.55 & 200 & .921 & \\
\hline$\sum_{i=1}$ & & $\mathrm{~K} 1 \mathrm{z}$ & 129 & 19.85 & 6.54 & 265 & -.764 & .446 \\
\hline 焉 & Orijinallik & Erkek & 138 & 20.46 & 6.69 & & & \\
\hline$:$ & Başlıkların & $\mathrm{K} 1 \mathrm{z}$ & 129 & 4.29 & 4.15 & 265 & .565 & .572 \\
\hline.$=$ & soyutluğu & Erkek & 138 & 4.02 & 3.50 & & & \\
\hline
\end{tabular}




\begin{tabular}{|c|c|c|c|c|c|c|c|c|}
\hline & \multirow[b]{2}{*}{ Zenginleştirme } & $\mathrm{K} 1 \mathrm{z}$ & 129 & 10.82 & 2.95 & \multirow{2}{*}{265} & \multirow{2}{*}{2.812} & \multirow{2}{*}{.005} \\
\hline & & Erkek & 138 & 9.79 & 3.04 & & & \\
\hline & \multirow{2}{*}{$\begin{array}{l}\text { Erken kapamaya } \\
\text { direnç }\end{array}$} & $\mathrm{K} 1 \mathrm{Z}$ & 129 & 13.53 & 3.66 & \multirow{2}{*}{265} & \multirow{2}{*}{2.007} & \multirow{2}{*}{.046} \\
\hline & & Erkek & 138 & 12.57 & 4.14 & & & \\
\hline & \multirow[b]{2}{*}{ Toplam yaratıcilık } & $\mathrm{K} 1 \mathrm{z}$ & 129 & 21.74 & 5.23 & \multirow{2}{*}{265} & \multirow{2}{*}{.646} & \multirow{2}{*}{.519} \\
\hline & & Erkek & 138 & 21.31 & 5.61 & & & \\
\hline KADEME & Yaratıcılık & Cinsiyet & $n$ & $X$ & $S$ & $\mathrm{Sd}$ & $\mathrm{t}$ & $p$ \\
\hline \multirow{12}{*}{$\stackrel{\sqrt[1]{A}}{\exists}$} & \multirow{3}{*}{ Akıcıllk } & $\mathrm{K} 1 \mathrm{z}$ & 145 & 21.03 & 7.75 & \multirow{2}{*}{268} & \multirow{2}{*}{-1.564} & \multirow{2}{*}{.119} \\
\hline & & Erkek & 125 & 22.52 & 7.90 & & & \\
\hline & & $\mathrm{K} 1 \mathrm{Z}$ & 145 & 17.72 & 6.86 & \multirow{2}{*}{268} & \multirow{2}{*}{-2.327} & \multirow{2}{*}{.021} \\
\hline & Orijinallik & Erkek & 125 & 19.65 & 6.73 & & & \\
\hline & \multirow{3}{*}{$\begin{array}{l}\text { Başlıkların } \\
\text { soyutluğu }\end{array}$} & Kiz & 145 & 6.53 & 4.67 & \multirow{2}{*}{268} & \multirow{2}{*}{5,181} & \multirow{2}{*}{, 000} \\
\hline & & Erkek & 125 & 3.87 & 3.59 & & & \\
\hline & & $\mathrm{K} 1 \mathrm{z}$ & 145 & 10.99 & 2.77 & \multirow{2}{*}{268} & \multirow{2}{*}{2.276} & \multirow{2}{*}{.024} \\
\hline & Zenginleştirme & Erkek & 125 & 10.20 & 2.95 & & & \\
\hline & \multirow{2}{*}{$\begin{array}{l}\text { Erken kapamaya } \\
\text { direnç }\end{array}$} & $\mathrm{K} 1 \mathrm{z}$ & 145 & 13.77 & 3.83 & \multirow{2}{*}{268} & \multirow{2}{*}{1.506} & \multirow{2}{*}{.133} \\
\hline & & Erkek & 125 & 13.05 & 4.06 & & & \\
\hline & \multirow[t]{2}{*}{ Toplam yaratıcilık } & Kiz & 145 & 22.67 & 5.47 & \multirow{2}{*}{268} & $100-$ & 040 \\
\hline & & Erkek & 125 & 21.36 & 5.33 & & & \\
\hline
\end{tabular}

Tablo 2'de anasınıfına, ilköğretim birinci ve ikinci kademeye ve liseye devam eden çocukların cinsiyetlerine göre yaratıcılıklarına ait ortalamalar, standart sapmalar ve t testi sonuçları verilmiştir. Yapılan t-Testi sonucunda, çocukların cinsiyetlerine göre anasınıfına devam eden çocuklarda akıcılık $\left(\mathrm{t}_{(90)}=2.258, p>.05\right)$; ilköğretim okulu ikinci kademeye devam eden çocuklarda zenginleştirme $\left(\mathrm{t}_{(265)}=2.812, p>.05\right)$ ve erken kapamaya direnç $\left(\mathrm{t}_{(265)}=2.007, p>.05\right)$; liseye devam eden çocuklarda orijinallik $\left(\mathrm{t}_{(268)}=-\right.$ $2.327, p>.05)$, başlikların soyutluğu $\left(\mathrm{t}_{(268)}=5.181, p>.05\right)$, zenginleştirme $\left(\mathrm{t}_{(268)}=2.276\right.$, $p>.05)$ alt boyutlarında ve toplam yaratıcılık puanında $\left(\mathrm{t}_{(268)}=1.985, p>.05\right)$ önemli bir fark olduğu gözlemlenmiştir. Anasıfınına, birinci ve ikinci kademeye ve liseye devam eden kız çocukların yaratıcılık puan ortalamalarının erkek çocuklarınkinden daha yüksek olduğu tespit edilmiştir $(p<0.05)$. 
Tablo 3

Anasınıfl, Illköğretim ve Liseye Devam Eden Çocukların Sinıf Düzeylerine Göre Yaratıcılıklarına Ait Ortalamalar ve Standart Sapmalar

\begin{tabular}{|c|c|c|c|c|}
\hline YARATICILIK & SINIFLAR & $n$ & $\bar{x}$ & $S$ \\
\hline \multirow{13}{*}{ Akıcıllk } & Anasinifi & 92 & 24.68 & 8.95 \\
\hline & 1.sinif & 91 & 21.92 & 8.16 \\
\hline & 2.sinif & 92 & 24.24 & 6.99 \\
\hline & 3. sinif & 90 & 23.09 & 7.93 \\
\hline & 4. $\sin 1 f$ & 92 & 21.66 & 7.97 \\
\hline & 5. $\sin 1 f$ & 91 & 24.22 & 7.93 \\
\hline & 6. sinif & 88 & 25.38 & 7.67 \\
\hline & 7. $\sin 1 f$ & 91 & 25.22 & 6.76 \\
\hline & 8.sinif & 88 & 24.26 & 8.00 \\
\hline & 9. $\sin 1 f$ & 90 & 25.93 & 7.61 \\
\hline & 10. sinif & 90 & 22.22 & 7.16 \\
\hline & 11.sinif & 90 & 17.00 & 6.01 \\
\hline & Toplam & 1085 & 23.32 & 7.94 \\
\hline \multirow[t]{6}{*}{ YARATICILIK } & SINIFLAR & $n$ & $\bar{x}$ & S \\
\hline & Anasınıfi & 92 & 20.13 & 10,27 \\
\hline & $1 . \sin 1 f$ & 91 & 15.29 & 7.30 \\
\hline & $2 . \sin 1 f$ & 92 & 17.15 & 6.10 \\
\hline & 3. sinif & 90 & 17.36 & 6.48 \\
\hline & 4. $\sin 1 f$ & 92 & 16.95 & 6.25 \\
\hline \multirow[t]{8}{*}{ Orijinallik } & 5. $\sin 1 f$ & 91 & 19.26 & 7.37 \\
\hline & 6. sinif & 88 & 20.25 & 7.12 \\
\hline & 7. sinif & 91 & 19.85 & 6.18 \\
\hline & $8 . \sin 1 f$ & 88 & 20.41 & 6.57 \\
\hline & 9. $\sin 1 f$ & 90 & 21.32 & 6.90 \\
\hline & 10. sinif & 90 & 19.10 & 6.32 \\
\hline & 11.sinif & 90 & 15.41 & 6.04 \\
\hline & Toplam & 1085 & 18.53 & 7.23 \\
\hline \multirow[t]{3}{*}{ YARATICILIK } & SINIFLAR & $n$ & $\bar{x}$ & $S$ \\
\hline & Anasınıfi & 92 & 1.14 & 1.85 \\
\hline & 1.sinif & 91 & .84 & 1.29 \\
\hline
\end{tabular}




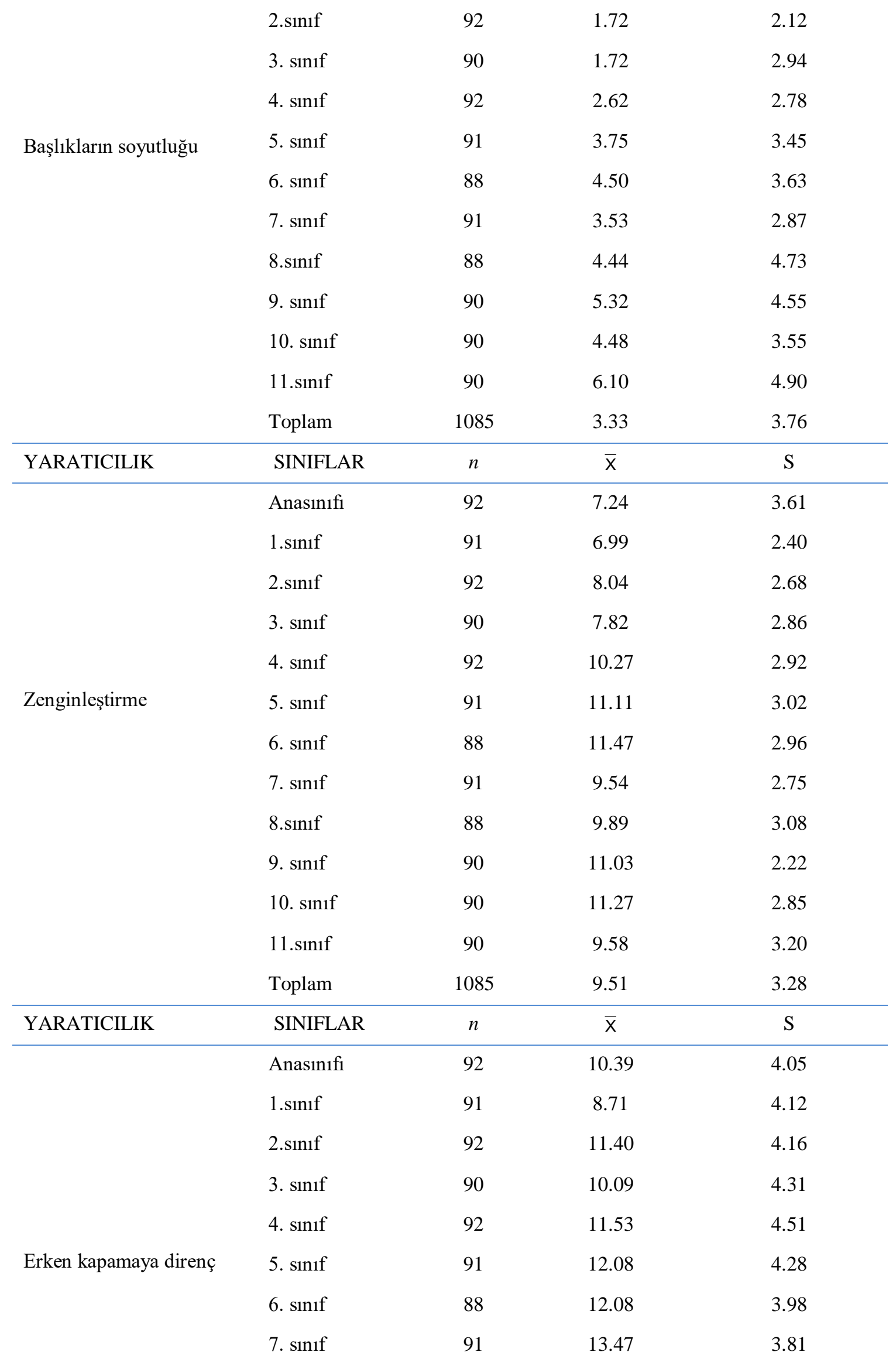




\begin{tabular}{|c|c|c|c|c|}
\hline & 8.sinif & 88 & 13.55 & 3.89 \\
\hline & 9. $\sin 1 f$ & 90 & 14.83 & 3.44 \\
\hline & 10. sinif & 90 & 13.14 & 3.51 \\
\hline & 11.sinif & 90 & 12.33 & 4.44 \\
\hline & Toplam & 1085 & 11.96 & 4.35 \\
\hline YARATICILIK & SINIFLAR & $n$ & $\bar{x}$ & S \\
\hline \multirow{13}{*}{ Toplam yaratıcılık } & Anasinifi & 92 & 20.50 & 4.68 \\
\hline & 1.sinif & 91 & 16.21 & 5.29 \\
\hline & 2.sinif & 92 & 18.22 & 4.21 \\
\hline & 3. $\sin 1 f$ & 90 & 17.13 & 5.21 \\
\hline & 4. $\sin 1 f$ & 92 & 19.20 & 5.32 \\
\hline & 5. $\sin 1 f$ & 91 & 20.10 & 6.10 \\
\hline & 6. $\sin 1 f$ & 88 & 21.90 & 5.21 \\
\hline & 7. $\sin 1 f$ & 91 & 20.83 & 5.00 \\
\hline & 8.sinif & 88 & 21.85 & 6.02 \\
\hline & 9. $\sin 1 f$ & 90 & 24.10 & 5.26 \\
\hline & 10. $\sin 1 f$ & 90 & 21.90 & 4.97 \\
\hline & 11.sinif & 90 & 20.20 & 5.40 \\
\hline & Toplam & 1085 & 20.24 & 5.64 \\
\hline
\end{tabular}

Yaratıcılık ölçeğinin akıcılık, orijinallik, erken kapamaya direnç alt boyutlarında ve toplamda 9. sınıfa devam eden çocuklarının puanlarının $[(\bar{x}=25.93),(\bar{x}=21.32)$, $(\bar{x}=14.83), \quad(\bar{x}=24.10)$ ], başlikların soyutluğu alt boyutunda 11. sınıfa devam eden çocuklarının puanlarının $(\bar{x}=6.10)$, zenginleştirme alt boyutunda ise 6 . sınıfa devam eden çocuklarının puanlarının $(\bar{x}=11.47)$ diğer sınıflardaki çocukların puanlarından daha yüksek olduğu görülmektedir (Tablo 3 ). 
Tablo 4

Anasınıfi, Illköğretim ve Liseye Devam Eden Çocukların Sinıf Düzeylerine Göre Yaratıcılıklarına Ait Varyans Analizi Sonuçları

\begin{tabular}{|c|c|c|c|c|c|c|}
\hline \multicolumn{7}{|c|}{ AKICILIK } \\
\hline Varyansın & Kareler & & Kareler & & & ANLAMLI FARK \\
\hline Kaynağ1 & Toplamı & $\mathrm{Sd}$ & Ortalamas1 & $\mathrm{F}$ & $p$ & \\
\hline Gruplararası & 5853.687 & 11 & 532.153 & 9.138 & .000 & 11.-(**AS, $2,3,5,6,7,8,9,10)$. \\
\hline Gruplariçi & 62488.881 & 1073 & 58.238 & & & \\
\hline Toplam & 68342.568 & 1084 & & & & \\
\hline
\end{tabular}

\begin{tabular}{lllllll}
\hline & & \multicolumn{5}{c}{ ORİJiNALLIK } \\
\hline $\begin{array}{l}\text { Varyansın } \\
\text { Kaynağ1 }\end{array}$ & $\begin{array}{l}\text { Kareler } \\
\text { Toplamı }\end{array}$ & Sd & $\begin{array}{l}\text { Kareler } \\
\text { Ortalaması }\end{array}$ & F & $p$ & ANLAMLI FARK \\
\hline Gruplararası & 4107.276 & 11 & 373.389 & 7.614 & .000 & $(1,11)-.(* *$ AS, 6, 8, 9.) \\
Gruplariçi & 52623.060 & 1073 & 49.043 & & & \\
Toplam & 56730.335 & 1084 & & & & \\
& & & & & &
\end{tabular}

\section{BAŞLIKLARIN SOYUTLUĞU}

\begin{tabular}{|c|c|c|c|c|c|c|}
\hline $\begin{array}{l}\text { Varyansın } \\
\text { Kaynağı }\end{array}$ & $\begin{array}{l}\text { Kareler } \\
\text { Toplamı }\end{array}$ & $\mathrm{Sd}$ & $\begin{array}{l}\text { Kareler } \\
\text { Ortalaması }\end{array}$ & $\mathrm{F}$ & $p$ & ANLAMLI FARK \\
\hline Gruplararası & 2940.675 & 11 & 267.334 & 23.238 & .000 & $\begin{array}{l}(* * A S, 1 .)-(5,6,7,8,9,10,11 .), \\
(2,3 .)-(6,8,9,10, \text { ve 11.), } 4-(9, \\
11 .), 5-11\end{array}$ \\
\hline Gruplariçi & 12343.878 & 1073 & 11.504 & & & \\
\hline Toplam & 15284.553 & 1084 & & & & \\
\hline
\end{tabular}

\section{ZENGINLEŞTIRME}

\begin{tabular}{lllllll}
\hline $\begin{array}{l}\text { Varyansın } \\
\text { Kaynağı }\end{array}$ & $\begin{array}{l}\text { Kareler } \\
\text { Toplamı }\end{array}$ & Sd & $\begin{array}{l}\text { Kareler } \\
\text { Ortalaması }\end{array}$ & F & $p$ & \multicolumn{2}{l}{ ANLAMLI FARK } \\
\hline Gruplararas 1 & 2629.499 & 11 & 239.045 & 28.431 & .000 & $\begin{array}{l}\text { (**AS, 1.) }(4,5,5,5,7,8,9,10,11 .), \\
10 .)\end{array}$ \\
Gruplariçi & 9021.650 & 1073 & 8.408 & & & \\
Toplam & 11651.148 & 1084 & & & & \\
\hline
\end{tabular}

\section{ERKEN KAPAMAYA DİRENÇ}

\begin{tabular}{lllllll}
\hline $\begin{array}{l}\text { Varyansın } \\
\text { Kaynağı }\end{array}$ & $\begin{array}{l}\text { Kareler } \\
\text { Toplamı }\end{array}$ & Sd & $\begin{array}{l}\text { Kareler } \\
\text { Ortalaması }\end{array}$ & F & $p$ & \multicolumn{2}{l}{ ANLAMLI FARK } \\
\hline Gruplararas 1 & 2859.312 & 11 & 259.937 & 15.790 & .000 & $\begin{array}{l}(* * A S, 3 .)-(7,8,9,10 .), 1-(2,4,5, \\
\text { (1) }\end{array}$ \\
Gruplariçi & 17663.822 & 1073 & 16.462 & & & \\
Toplam & 20523.134 & 1084 & & & & \\
\hline
\end{tabular}




\section{TOPLAM YARATICILIK}

\begin{tabular}{|c|c|c|c|c|c|c|}
\hline $\begin{array}{l}\text { Varyansın } \\
\text { Kaynağı }\end{array}$ & $\begin{array}{l}\text { Kareler } \\
\text { Toplamı }\end{array}$ & $\mathrm{Sd}$ & $\begin{array}{l}\text { Kareler } \\
\text { ortalamas1 }\end{array}$ & $\mathrm{F}$ & $p$ & ANLAMLI FARK \\
\hline Gruplararası & 4974.468 & 11 & 452.224 & 16.465 & .000 & $\begin{array}{l}(* * A S, 4,11 .)-9,1-(5,6,7,8,9,10, \\
11), 2-(6,8,9 . \text { ve 10.), 3-(5, 6, 7, 8, } \\
9,10 .)\end{array}$ \\
\hline Gruplariçi & 29471.506 & 1073 & 27.466 & & & \\
\hline Toplam & 34445.974 & 1084 & & & & \\
\hline
\end{tabular}

Tablo 4'te anasınıfına, ilköğretim birinci ve ikinci kademeye ve liseye devam eden çocukların sınıf düzeylerine göre yaratıcılıklarına ait varyans analizi sonuçları verilmiştir. Yapılan varyans analizi sonucunda akıcılık $(\mathrm{F}(11.1073)=9.138 ; p<0.05)$; orijinallik $(\mathrm{F}(11.1073)=7.614 ; p<0.05)$; başlıkların soyutluğu $(\mathrm{F}(11.1073)=23.238 ; p<$ $0.05)$; zenginleştirme $\quad(\mathrm{F}(11.1073)=28.431 ; \quad p<0.05)$; erken kapamaya direnç $(\mathrm{F}(11.1073)=15.790 ; p<0.05)$; alt boyut puanlarının ve toplam yaratıc1lı puanının $(\mathrm{F}(11.1073)=16.465 ; p<0.05)$ çocukların devam ettikleri sinıf düzeylerine göre farklılaştığı saptanmıştır. Farklılı̆ı̆ı kaynağını belirlemek amacıyla uygulanan Scheffe Testi sonucunda; anasınıfi, 2, 3, 5, 6, 7, 8, 9 ve 10. sinıflara devam eden çocukların, 11. sinıftakilere göre akıcılık alt boyut puanlarının daha yüksek olduğu sonucuna ulaşılmıştır. Orijinallik alt boyutunda anasınıfi, 6, 8 ve 9. sınıflara devam eden çocukların, 1. ve 11. sınıflara devam eden çocuklara göre daha yüksek puan aldıkları belirlenmiş̧tir. Başlıkların soyutluğu alt boyut ortalamalarının 5, 6, 7, 8, 9, 10 ve 11 . sinfflara devam eden çocukların, anasınıfı ve 1 . sınıfa devam edenlerin ortalamalarına göre daha yüksek olduğu saptanmıştır. $6,8,9,10$ ve 11 . sinıflara devam etmekte olan çocukların, 2 ve 3 . sınıfa devam edenlere göre başlıkların soyutluğu alt boyut puanlarının daha yüksek olduğu belirlenmiştir. 9. ve 11. sınıflara devam eden çocukların başlıkların soyutluğu alt boyut puanlarının 4. sınıfa devam eden çocuklarınkinden ve 11. sınıfa devam eden çocukların başlıkların soyutluğu puanlarının 5. sınıfa devam eden çocuklarınkinden daha yüksek olduğu saptanmıştır. Zenginleştirme alt boyutuna bakıldığında $4,5,6,7,8,9,10$ ve 11 . sınıflara devam eden çocukların puanlarının, anasınıfı ile 1. sınıfa devam edenlerinkine göre daha yüksek olduğu; 4, 5, 6, 9 ve 10. sınıflara devam eden çocukların puanlarının, 2. sınıfa devam edenlerinkine göre daha yüksek olduğu; 4, 5, 6, 8, 9 ve 10. sinıflara devam eden çocukların puanlarının, 3. sınıfa devam edenlerinkine göre daha yüksek olduğu saptanmıştır. Zenginleştirme puanlarının sınıf düzeyi yükseldikçe artı̧ gösterdiği görülmektedir. Erken kapamaya direnç alt boyut puanlarının, 7, 8, 9 ve 10. sınıflara devam etmekte olan çocukların, anasınıfina ve 3. sınıfa devam edenlerinkine göre daha yüksek olduğu belirlenirken; 2 , 4, 5, 6, 7, 8, 9, 10 ve 11. sınıflara devam eden çocukların, 1. sınıfa devam edenlerinkine göre daha yüksek olduğu saptanmıştır. 9. sınıfa devam etmekte olan çocukların puanlarının ise, 2, 4,5 ve 6 . devam edenlerinkine göre daha yüksek olduğu belirlenmiştir. 9. sınıflara devam etmekte olan çocukların toplam yaratıcılık puanlarının anasınıfı, 4. sınıf ve 11 . 
sınıftakilerinkine göre daha yüksek olduğu saptanmıştır. Yine toplam yaratıcılık puanlarının 5, 6, 7, 8, 9, 10 ve 11. sinıflara devam eden çocukların, 1. sınıftakilerinkine göre; 6, 8, 9 ve 10. sinıflara devam eden çocukların, 2. sınıftakilerinkine göre; 5, 6, 7, 8, 9 ve 10. sınıflara devam eden çocukların, 3. sınıftakilerinkine göre daha yüksek olduğu sonucuna ulaşılmıştır.

\section{Sonuç ve Tartışma}

Anasınıfına, ilköğretim birinci ve ikinci kademeye ve liseye devam eden çocukların yaratıcılıklarının incelenmesi amacıyla yapılan bu araştırmanın sonuçlarına bakıldığında; anasınıfına devam eden çocuklarda akıcılık, ilköğretim okulu ikinci kademeye devam eden çocuklarda zenginleştirme ve erken kapamaya direnç, liseye devam eden çocuklarda orijinallik, başlıkların soyutluğu, zenginleştirme alt boyutlarında ve toplam yaratıcılık puanında kız ve erkek çocukların puanları arasında farkın önemli olduğu gözlemlenmiştir. Anasıfına, birinci ve ikinci kademeye ve liseye devam eden kız çocukların yaratıcılık puan ortalamalarının erkek çocuklarınkinden daha yüksek olduğu tespit edilmiştir (Tablo 2). Alan yazın incelendiğinde de, genellikle, kızların yaratıcılıklarının erkeklerden daha yüksek olduğu görülmektedir. Öncü (2003) 12-14 yaşları arasındaki çocukların yaratıcılık düzeylerinin belirlenmesi amacıyla, Lee (2005)'nin de 4 ve 5 yaş anaokulu çocuklarının yaratıcı düşünce ve yaratıcı kişilikleri üzerine yaptığı araştırma sonuçlarında, cinsiyetin yaratıcılık düzeyi ve yaratıcı düşünce üzerinde etkisinin olduğu sonucunu ortaya çıkarmışlardır. Matud, Pilar, Rodríguez, ve Grande (2007) yaptıkları çalışmada farklı eğitim seviyelerinde cinsiyet farklılığının yaratıcı düşünme üzerine etkisine bakmışlardır. Elde edilen sonuçlara göre; ilk ve lise seviyesindeki kızların yaratıcılık puanları, orijinallik ve yaratıcılık indeksi bakımından erkeklere göre daha yüksek bulunmuştur.

Çocukların devam ettikleri sınıf düzeyinin yaratıcılık üzerinde etkili olup olmadığı belirlemek için yapılan analizler sonucunda, sınıf düzeyinin yaratıcılık üzerinde etkili olduğu saptanmıştır. Yaratıcılığın tüm alt boyutlarında ve toplamda anasınıfına devam eden çocukların puan ortalamalarının $\left[\left(\bar{x}_{A}=24.68\right) \quad\left(\bar{x}_{O}=20.13\right)\right.$ $\left.\left(\overline{\mathrm{x}}_{\mathrm{BS}}=1.14\right) \quad\left(\overline{\mathrm{x}}_{\mathrm{Z}}=7.24\right) \quad\left(\overline{\mathrm{x}}_{\mathrm{EKD}}=10.39\right) \quad\left(\overline{\mathrm{x}}_{\mathrm{TOP}}=20.50\right)\right]$, birinci sinifa devam eden çocukların puan ortalamalarından $\left[\left(\bar{x}_{A}=21.92\right) \quad\left(\bar{x}_{O}=15.29\right) \quad\left(\bar{x}_{B S}=.84\right) \quad\left(\bar{x}_{Z}=6.99\right)\right.$ $\left(\bar{x}_{\text {EKD }}=8.71\right) \quad\left(\bar{x}_{\text {TOP }}=16.21\right)$ ] daha yüksek olduğu görülmektedir (Tablo 3-Tablo 4). Moran, Sawyers ve Moore (1983) yaptıkları bir çalışmada, okulöncesi çocuklarının daha büyük yaştaki çocuklara göre daha büyük bir oranda orijinal tepki gösterdiklerini bulmuşlardır. Bu bulgular formal okul yaşantısı ve derslerine daha çok zaman harcayan okul çocuklarının sınırlandırılmış ve orijinal düşünmeye izin vermeyen eğitim programlarından etkilendiğini göstermektedir. Okulöncesi dönemindeki çocuklar, katı kurallarla belirlenmiş formal okul yaşantısı ve dersleriyle henüz karşılaşmadıkları ve daha özgür bir eğitim ortamında oldukları için yaratıcılıkları daha yüksek olabilmektedir (Isenberg ve Jalongo 1973). Tüm sınıf düzeylerindeki toplam yaratıcılık puanlarına bakıldığında 1, 2 ve 3 sınıfa devam eden çocukların puanlarının genel olarak 5. ve daha üst sınıflardaki çocukların puanlarından daha düşük olduğu, 3. sınıftan sonra yaratıcılık 
puanlarının yükseldiği görülmektedir. Alacapınar (2013) yaptığ1 bir araştırmada, ilköğretim okulu 3. sınıftan 8. sınıfa kadar olan çocukların yaratıcılıkları incelemiştir. 5. sınıfa devam eden çocukların akıcılık, esneklik, özgünlük, süsleme ve toplam puanlarının diğer sınıflara göre daha yüksek olduğu; yaratıcılık puanların 3. sınıftan 5 . sınıfa doğru yükseldiği sonucuna ulaşmıştır. Öncü (2003) tarafindan yapılan araştırma sonucunda 14 yaşındaki çocukların zenginleştirme puanlarının, 12 ve 13 yaşındakilerin zenginleştirme puanlarından daha yüksek olduğu belirlenmiştir. Yontar (1993) yaptığ 1 boylamsal bir çalışmada, yedi yıl boyunca Torrance Yaratıcı Düşünce Testi Şekil A Formu'nu öğrencilere üç kez uygulamış; akıcılık ve esneklik boyutlarında 11. sınıflar aleyhine bir farklılık olduğunu gözlemlemiştir.

\section{Öneriler}

Anasınıfına, ilköğretim birinci ve ikinci kademeye ve liseye devam eden çocukların yaratıcılıklarının incelenmesi amacıyla yapılan araştırmada elde edilen bulgular doğrultusunda eğitimcilere ve araştırmacılara aşağıdaki öneriler sunulabilir;

Yaratıcılığın geliştirilebilmesi için eğitimci niteliklerinin ve sınıf atmosferinin önemi tartışılmaz bir gerçektir. Ayrıca, çocuklarda yaratıcı düşünmenin geliştirilebilmesi sürecinde öncelikle çocuklar için model olan eğitimcinin yaratıcı becerilere sahip olması gerekmektedir. $\mathrm{Bu}$ açıdan hizmet öncesi eğitimde eğitimci adaylarının yaratıcı düşünme becerilerini destekleyen derslere yer verilebilir ve bu derslerin içeriğinde çocukların yaratıcılıklarının geliştirilmesinin yanı sıra öğretmen adaylarının yaratıcılıklarını geliştirmeye yönelik çalışmalar da yapılabilir. Anasınıfı, sınıf ve branş öğretmenlerinin sınıfta yaratıcılığın geliştirilmesine yönelik farkındalıklarını artıracak hizmet içi eğitim seminerleri düzenlenebilir.

$\mathrm{Bu}$ araştırmada anaokulu, ilköğretim ve liselere devam eden çocukların yaratıcılıkları incelenmiştir. Anasınıfında olan çocukların yaratıcılıklarının ilköğretimin başlangıcında olan çocukların yaratıcılıklarından daha yüksek olduğu, özellikle de ilköğretimin ilk üç sınıfında yaratıcılıkları düşük olan çocukların ilerleyen sınıflarda yaratıcılıklarının arttığı sonucuna ulaşılmıştır. İlköğretimin başlangıcında çocukların yaratıcılıklarının düşme nedenlerini belirlemeye yönelik araştırmalar planlanabilir. Çocukların yaratıcılığı önünde engel olan ya da yaratıcılığı geliştiren eğitimci özelliklerini belirlemek hedeflenebilir. Eğitimcilerin yanı sıra çocukların yaşamında önemli olan anne babaların yaratıcılıklarını, anne babalar ile çocukların yaratıcılıkları arasında ilişkileri belirlemeye yönelik araştırmalar planlanabilir. 


\section{Kaynakça}

Alacapınar, F. G. (2013). Grade level and creativity. Eğitim Araştırmaları-Eurasian Journal of Educational Research, 50, 247-266.

Akçum, E. (2005). 5-6 yaş çocuklarının yaratıcılık ve ögrenime hazır oluş düzeylerine okulöncesi eğitimin etkisinin incelenmesi (Yayımlanmamış yüksek lisans tezi). Selçuk Üniversitesi, Konya.

Aral, N. (1992). Farkl sosyo-ekonomik düzeydeki ortaokul son sinıfa devam eden öğrencilerin yaratıcılıkları ile ilgi alanlarının bazı değişkenlere göre incelenmesi (Yayımlanmamış doktora tezi). Hacettepe Üniversitesi, Ankara.

Aral, N. (1996). Dokuz ve on dört yaşlarındaki çocukların yaratıcılıkları ile sosyoekonomik düzey ve cinsiyet arasındaki ilişkinin incelenmesi. Eğitim ve Bilim, 20(101), 65-72.

Aral, N. (2004). Çocukta yaratıcılığın gelişimi. Çoluk Çocuk Anne Baba Eğitimci Dergisi, 36, 23-25.

Aral, N., Köksal-Akyol, A., \& Çakmak, A. (2007). Okul öncesi öğretmen adaylarının yaratıcılıkları üzerinde drama eğitiminin etkisinin incelenmesi. A. Yılmaz ve F. Gürsul (Ed.) içinde, Uluslararası Öğretmen Yetiştirme ve Sorunları Sempozyumu Bildiri Kitabı (ss. 149-153). Bakü: Azerbaycan Devlet Pedagoji Üniversitesi.

Argun, Y. (2004). Okul öncesi dönemde yaratıcılık ve eğitimi. Ankara: Anı Yayıncılık.

Aslan, E. (2001). Torrance Yaratıcı Düşünce Testi'nin Türkçe versiyonu. Marmara Üniversitesi Atatürk Ĕ̆itim Fakültesi Eğitim Bilimleri Dergisi, 14, 19-40.

Aslan, A.E.(2007). Yaratıcı düşünce eğitimi. A.Oktay ve Ö.P.Unutkan (Ed.) içinde, Illköğretim çă̆ına genel bir bakış (ss.75-101). İstanbul: Morpa Kültür Yayınları.

Ataman, A. (1995). Eğitim sürecinde yaratıcılık. Yaratıcılık ve Eğitim. Türk Eğitim Derneği Yayınları Dizi No:17. Ankara: Şafak Matbaacılık.

Atay, Z. (2009). Okul öncesi ĕgitim kurumlarına devam eden 5-6 ögrencilerinin yaş, cinsiyet ve ebeveyn eğitim durumlarına göre incelenmesi: Ereğli örneği (Yayımlanmamış yüksek lisans tezi). Selçuk Üniversitesi, Konya.

Beretta, S., \& Privette, G. (1990). Influence of play on creative thinking. Perceptual \& Motor Skills, 71(2), 659-666.

Black, R.A. (2003). Kırık mum boyalar: Yaratıcılığınızı geliştirmek için yol haritası (E. Aslan, Çev.). Ankara: Nobel Yayın Dağıtım.

Büyüköztürk, Ş. (2007). Sosyal bilimler için veri analizi el kitabı istatistik, araştırma deseni SPSS uygulamalart ve yorum. Ankara: Pegem A Yayıncılık.

Ceylan, E. (2008). Okul öncesi eğitime devam eden 5-6 yaş çocuklarının bilişsel tempoya göre yaratıcılı düzeylerinin incelenmesi (Yayımlanmamış yüksek lisans tezi). Selçuk Üniversitesi, Konya.

Cho, B., \& Kim, J. (1999). The Improvement of children's creativity through Korean Picture Books. Child Education, 75(6), 337-341. 
Çağatay-Aral, N. (1990). Alt ve üst sosyo-ekonomik düzeydeki dokuz yaş grubu kız ve erkek çocukların yaratıcılıklarını etkileyen bazı faktörler üzerine bir araştırma. (Yayımlanmamış doktora tezi). Ankara Üniversitesi, Ankara.

Çakmak, A. (2005). Anasınıfina devam eden altı yaşındaki köy ve kent çocuklarının yaratıcılıklarının çeşitli değişkenlere göre incelenmesi (Kırıkkale örneği) (Yayımlanmamış yüksek lisans tezi). Ankara Üniversitesi, Ankara.

Çakmak, A., \& Barran, G. (2006).. Köyde ve kentte yaşayan altı yaş çocuklarının yaratıcılıklarının karşılaştırılması. N. Aral ve B. Tuğrul (Ed) içinde, Avrupa Birliği Sürecinde Okul Öncesi Ĕgitimin Geleceği Sempozyumu (Uluslararası Katılımlı) Bildiriler Kitabı (ss:154-169). İstanbul: YA-PA Yayınları.

Dinçer, D. (1993) Anaokuluna devam eden beş yaş grubu çocukların anne-baba tutumları ile yaratıcı düşünmeleri arasındaki ilişkinin incelenmesi (Yayımlanmamış yüksek lisans tezi). Marmara Üniversitesi, İstanbul.

Erlendsson, J. (1999). The role of creativity, University of Iceland, http://www.hi.is/ joner/eaps/cq_cr04.htm Erişi Tarihi: 30 Ekim 2013.

Ersoy, E., \& Başer, N. (2009). İlköğretim 6. sınıf öğrencilerinin yaratıcı düşünme düzeyleri. Uluslararası Sosyal Araştırmalar Dergisi, 2(9), 129-137.

Goree, K. (1996). Creativity in the classroom. Do we really want it? Gifted Child Today Magazine, 19(4), 36.

Güleryüz, H. (2001). Eğitim programlarının dili ve yaratıcı öğrenme. Ankara: Pegem Akademi Yayıncılık.

Isbell, R. T., \& Raines, S. C. (2003). Creativity and the arts with young children. Clifton Park, NY : Thomson/Delmar Learning.

Isenberg, J.P., \& Jalongo, M.R. (1997). Creative expression and play in early chilhood. London: Prentice Hall.

Kamaraj, I., \& Aktan, E. (1998). Okul öncesi eğitimde yaratıcılık ve problem çözme becerisi. Çă̆daş Ĕgitim, 244, 55-60.

Lee, K.H. (2005). The relationship between creative thinking ability and creative personality of preschoolers. International Education Journal, 6(2), 194-199.

Mangır, M. \& Aral, N. (1992). Çocukta yaratıcılık ve yaratıcılığın geliştirilmesi. 8. YAPA Okulöncesi Ĕgitimi ve Yaygınlaştırılması Semineri Kitabı (ss. 41-50), İstanbul: Ya-Pa Yayınlar1.

Matud, M.P., Rodriguez, C., \& Grande, J. (2007). Gender differences in creative thinking. Tenerife, ESPAGNE: Facultad de Psicología, Universidad de La Laguna, Campus de Guajara. http://cat.inist.fr/?aModele=afficheN\&cpsidt=18957305 Erişi Tarihi: 30 Ekim 2013.

Mayesky, M. (2002). Creative activities for young children (7th ed.). Albany/ New York: Delmar/Thomson Learning. 
Moran, D. J., Sawyers, J. K., \& Moore, A. J. (1988). The effects of structure in instructions and materials on preschoolers' creativity. Home Economics Research Journal 17(2), 148-152.

Ömeroğlu, E., \& Turla A. (2001). Okulöncesi dönemde yaratıcılık eğitimi ve desteklenmesi. Milli Ĕ̆itim Dergisi, 151, 48-52.

Öncü, T. (1989). Torrance yaratıcı düşünme testleri ve wartegg-biedma testi aracılığıyla 7-11 yaş çocuklarının yaratıcılı̆̆ı ve kişilik yapıları arasındaki ilişkinin incelenmesi (Yayınlanmamış doktora tezi). Ankara Üniversitesi, Ankara.

Öncü, T. (2003). Torrance yaratıcı düşünme testleri-şekil testi aracılığıyla 12-14 yaşları arasındaki çocukların yaratıcılık düzeylerinin yaş ve cinsiyete göre karşılaştırılması. Ankara Üniversitesi Dil ve Tarih Coğrafya Fakültesi Dergisi, 43(1), 221-237.

Rowe, A. J. (2007). Yaratıcı zeka (Ş. Gülmen, Çev.). İstanbul: Prestij Yayınları,

San, İ. (1979) Sanatsal yaratma ve çocukta yaratıcılık. Ankara: T.C. İş Bankası Yayınc1lik.

San, İ. (1981). Sanat ve eğitim. Ders Notu Teksir No: 5. Ankara: Ankara Üniversitesi Eğitim Araştırmaları Merkezi.

San, İ. (1985). Sanat ve eğitim. Ankara Üniversitesi Eğitim Bilimleri Fakültesi Yayınları, No: 151. Ankara: Ankara Üniversitesi Basımevi.

Sönmez, V. (1993). Yaratıcı eğitim. Yaratıcılık ve Eğitim, XVII. Eğitim Toplantısı, A. Ataman (Ed.), Ankara: Türk Eğitim Derneği Yayını.

Sungur, N. (2001). Yenilik yaratıcılık demokrasi. Yaratıcı okul düşünen sınıflar (1. Basım). İstanbul: Evrim, (Sistem Ofset)

Torrance, E.P. (1962). Guiding creative talent. Englewood Cliffs, N.J: Prentice-Hall.

Torrance, E.P. \& Goff, K., (1989). A Quiet revolution. Journal of Creative Behavior, 23(2), 136-145.

Yıldız, F.Ü. (2000). Deneysel yaratıcılık programının 4-5 yaş çocuklarının sosyal ve bilişsel gelişimlerine etkileri (Yayımlanmamış yüksek lisans tezi). Selçuk Üniversitesi, Konya.

Yıldız, V., Özkal, N., \& Çetingöz, D. (2003). Okul öncesi eğitimi alan ve almayan 7-8 yaş grubu çocuklarda yaratıcı potansiyelin değerlendirilmesi. Eğitim Araştırmaları Dergisi, 4(13), 129-137.

Yontar, A. (1993). Insanda yaratıcılı̆̆ın gelişimi. Yaratıcılık ve Eğitim. (XVII. Eğitim Toplantısı) A. Ataman (Ed.) Türk Eğitim Derneği, Eğitim Dizisi No: 17, Ankara: Şafak Matbaacılık. 